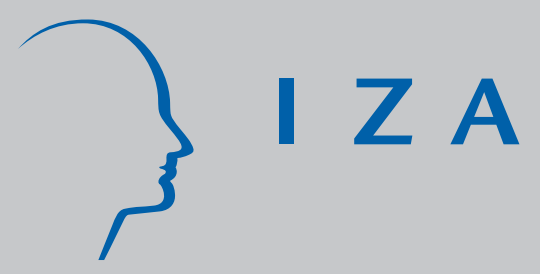

IZA DP No. 3291

Teamwork and Intra-Firm Wage Dispersion among Blue-Collar Workers

Uwe J irjahn

Kornelius Kraft

J anuary 2008 


\title{
Teamwork and Intra-Firm Wage Dispersion among Blue-Collar Workers
}

\author{
Uwe Jirjahn \\ University of Hannover
}

Kornelius Kraft

University of Dortmund, ZEW and IZA

Discussion Paper No. 3291
January 2008

\author{
IZA \\ P.O. Box 7240 \\ 53072 Bonn \\ Germany \\ Phone: +49-228-3894-0 \\ Fax: +49-228-3894-180 \\ E-mail: iza@iza.org
}

Any opinions expressed here are those of the author(s) and not those of IZA. Research published in this series may include views on policy, but the institute itself takes no institutional policy positions.

The Institute for the Study of Labor (IZA) in Bonn is a local and virtual international research center and a place of communication between science, politics and business. IZA is an independent nonprofit organization supported by Deutsche Post World Net. The center is associated with the University of Bonn and offers a stimulating research environment through its international network, workshops and conferences, data service, project support, research visits and doctoral program. IZA engages in (i) original and internationally competitive research in all fields of labor economics, (ii) development of policy concepts, and (iii) dissemination of research results and concepts to the interested public.

IZA Discussion Papers often represent preliminary work and are circulated to encourage discussion. Citation of such a paper should account for its provisional character. A revised version may be available directly from the author. 
IZA Discussion Paper No. 3291

January 2008

\section{ABSTRACT}

\section{Teamwork and Intra-Firm Wage Dispersion among Blue-Collar Workers}

Using data on a sample of manufacturing establishments in Germany, we find that the use of self-managed teams is associated with increased intra-firm wage inequality between skilled and unskilled blue-collar workers. We also show that moderating factors play an important role. While teamwork interacts positively with employer-provided further training and a production technology of the most recent vintage, it interacts negatively with the age of the establishment and the coverage by a collective bargaining agreement.

JEL Classification: J30, J31, M52

Keywords: wage inequality, skill-biased organizational change, training, technology, establishment age, collective bargaining

Corresponding author:

Kornelius Kraft

Department of Economics

University of Dortmund

Vogelpothsweg 87

D-44227 Dortmund

Germany

E-mail: kornelius.kraft@uni-dortmund.de 


\section{Introduction}

Teamwork is a key feature of high performance work (HPW) systems. The literature on HPW practices has grown rapidly in the last decade or so, and by now we have a rich collection of evidence on these practices. Yet, most of studies examine the effects on firm performance. Relatively little is known about the wage effects of HPW practices. As Handel and Levine (2004: 3) put it:

$$
\begin{aligned}
& \text { 'Many of the early studies focused on the implications of new work } \\
& \text { practices for organizational outcomes such as productivity and } \\
& \text { profitability, where the evidence remains mixed.... Untily quite } \\
& \text { recently, systematic research on the implications for employees has } \\
& \text { been less common, and the evidence remains at least very mixed.' }
\end{aligned}
$$

We contribute to the literature by examining the relationship between self-managed teams and intra-firm wage dispersion among blue-collar workers. The literature on skill-biased technological change usually views blue-collar workers as a homogeneous indicator of lowskilled employees. Yet, not only technological change but also organizational change can be skill-biased. Team production involves increased responsibility, expanded involvement in decision making, and more complex tasks. Hence, it entails higher skill requirements. Bluecollar workers are those workers who are directly involved in team production. This suggests that it is important to distinguish between skilled and unskilled blue-collar workers.

Using data on a sample of manufacturing establishments in Germany, we find that the use of self-managed teams is associated with increased intra-firm wage inequality between skilled and unskilled blue-collar workers. This finding fits the hypothesis that skilled bluecollar workers play a crucial role in team production. We argue that teamwork involves an increased specialization of unskilled and skilled blue-collar workers within establishments. Team production implies that skilled blue-collar workers have an increased responsibility for complex and difficult tasks while possibly only routine tasks are left for unskilled blue-collar 
workers. Hence, the employer has an increased incentive to provide differential rewards to skilled and unskilled blue-collar workers.

Moreover, we take into account that the link between team production and intra-firm wage inequality may vary according to circumstances and the type of firm. While the literature on HPW practices and establishment performance routinely emphasizes the role of interaction effects, the literature on the wage effects of HPW practices has been essentially silent on the role of moderating factors. Almost all of the studies implicitly assume a uniform relationship between HPW practices and wages. This may explain the mixed results in this literature.

Our results highlight four interaction effects. First, the use of self-managed teams interacts positively with employer-provided further training. Such an interaction effect can be expected if team production widens the training gap between skilled and unskilled workers. As skilled blue-collar workers play an important role in team production, the employer is likely to invest an even larger amount in their training. This reinforces the rise in wage inequality. Second, self-managed teams interact positively with a production technology of the most recent vintage. New production technologies substitute for routine tasks and require skilled workers with increased responsibility to run and operate them. Hence, a state-of-theart technology reinforces the role of skilled team members. Third, the use of self-managed teams interacts negatively with the age of the establishment. Older establishments with inflexible routines and a more bureaucratic organization may face difficulties in finding new pay policies that complement team production. Fourth, self-managed teams interact negatively with the coverage by a collective bargaining agreement. Collective agreements are usually negotiated between unions and employers' association on a broad industrial level. As they define a lower bound on wages, the negative interaction effect suggests that collective agreements prevent a downward adjustment in unskilled wages.

The rest of the paper is organized as follows. Section 2 gives a detailed discussion of 
the theoretical background. Section 3 provides a review of previous empirical studies. Section 4 describes the data and variables. Section 5 presents the results while Section 6 concludes.

\section{Background Discussion}

\subsection{Teamwork and Wage Inequality within Establishments}

Since the 1970s wage dispersion has been dramatically rising in the United States. The large increase in inequality has resulted from both higher skilled wages and lower unskilled wages. In contrast, in many continental European countries, most notably in Germany, the distribution of wages was very stable for a long time (Freeman and Katz 1995). The picture has changed recently. In the meantime, even Germany experienced an increase in wage dispersion, starting in the early 1990s (Gernadt and Pfeiffer 2006, Kohn 2006, Moller 2005).

Rising wage inequality is usually attributed to skill-biased technological change. According to this view, new technologies substitute for unskilled workers in routine tasks while they complement skilled workers in performing complex nonroutine tasks (Acemoglu 2002, Autor et al. 2003, Galor and Moav 2000). The resulting rise in wage dispersion may be reinforced if new technologies lead firms to invest more in the training of skilled workers and to reallocate physical capital from unskilled to skilled jobs. However, the wage effects of technological change can depend critically on the type of technology being adopted. Doms et al. (1997) show that computer investments are associated with skill upgrading while factory automation technologies directly used in the production of manufactured goods have little influence. This might suggest that skill-biased technological change increases the skill requirements for managerial and clerical employees rather than for production workers. ${ }^{1}$

While the earlier literature has mainly focused on technological change, a few recent studies stress that also organizational change can be skill-biased (Bresnahan et al. 2002, Caroli and Van Reenen 2001). This change is characterized by an increasing use of HPW practices. The delegation of decision rights and the decentralization of authority aim at 
improving the flexible use of local information available at lower layers of hierarchy (Aoki 1990). This entails higher skill requirements for lower-level employees as they increasingly have to engage in more complex tasks. Importantly, the use of HPW practices involves a reorganization of work at the shop floor level. Hence, skill-biased organizational change also applies to blue-collar workers.

Organizing blue-collar workers in self-managed production teams with increased responsibility and expanded involvement in decision making is typically viewed as a key feature of HPW systems (Osterman 1994). This brings us to the issue of skill diversity among team members. Theoretical models by Acemoglu (1999), Kremer and Maskin (1996) and Thesmar and Thoenig (2000) suggest that technological and organizational change leads to an increased segregation of the labor market with skilled workers being predominantly employed in establishments with teamwork and low-skilled workers primarily employed in traditional establishments without teamwork.

However, evidence provided by Hamilton et al. (2003) shows that skill diversity is advantageous. They examine a garment factory in which sewing initially was divided into independent tasks. The factory changed the organization of its sewing activity to module production, in which autonomous teams perform all sewing tasks. Hamilton et al. (2003) find that heterogeneous teams are more productive, with average ability held constant. ${ }^{2}$

This evidence complements several theoretical analyses. As heterogeneous team members have different backgrounds, experiences and heuristics, the team can exploit new opportunities (Hong et al. 2004, Lazear 1999, Mello and Ruckes 2006, Prat 2002). Diversity in skills and abilities allows the team to draw on different sources of information and enables creative problem solving. Thus, a heterogeneous team of workers with different skills and levels of skills can outperform a homogeneous team of high-skilled workers with similar backgrounds.

Furthermore, heterogeneous teams facilitate communication and mutual help among 
low-skilled and high-skilled workers. This may enable a more efficient specialization of lowskilled and high-skilled team members. ${ }^{3}$ If there is little opportunity for communication, lowskilled wokers cannot fully pass problems to high-skilled colleagues. Hence, to some extent, they have to solve those problems on their own. Yet, if teamwork provides opportunities for communication, low-skilled team members can ask their high-skilled colleagues for help to solve difficult tasks. In exchange, high-skilled workers delegate routine tasks to low-skilled team members. This allows high-skilled workers to focus on the more complex tasks as they get disburdened from routine work. Hence, while teamwork involves a flattening of formal hierarchies within firms, it may also entail an increased specialization of unskilled and skilled blue-collar workers at the shop floor level.

This line of reasoning suggests that skilled workers play a crucial role in the performance of heterogeneous teams. They have increased responsibility for complex tasks and help low-skilled workers to handle difficulties (Hansen 1997). Similarly, Bell and Hart (1999) argue that high-skilled workers do overtime to clear faults of other team members or to perform the tasks of colleagues who are absent due to illness. This is important as teams are characterized by a high degree of interdependent worker productivity (Heywood and Jirjahn 2004). The performance of a single worker does not only affect the worker's own output but also the entire team.

Moreover, high-skilled workers can play a leadership role within heterogeneous teams. Aghion et al. (1999) argue that the managers of the firm concentrate delegated decision rights on a small number of high-skilled team leaders to avoid moral hazard. Team production as a coordination game may, indeed, involve multiple equilibria. A leader can help to reach a high effort equilibrium by coordinating the complementary actions of the team members (Foss 2001). Leading by example (exerting high effort) may be one way in which the leader creates the common belief that the team will indeed move to the high effort equilibrium. High-skilled workers may also establish a group norm of high productivity by exerting pressure on low- 
skilled workers. Experimental evidence by Falk and Ichino (2006) indicates that low-skilled workers are very sensitive to peer effects. This is confirmed by a case study by Mas and Moretti (2006). Furthermore, like Hamilton et al. (2003), Mas and Moretti (2006) also show that skill diversity is associated with increased performance.

If skilled workers play a crucial role in the success of teams, incentives are required to particularly ensure that skilled team members exert effort. Hence, it appears reasonable to the firm to provide differential rewards to skilled and unskilled team members. This means that skilled team members receive larger rewards for good team performance than unskilled team members. ${ }^{4}$ Jirjahn and Kraft (2007) confirm that group performance pay as a proxy for underlying team production has a stronger positive impact on productivity when coupled with a higher wage differential between skilled and unskilled blue-collar workers. Of course, team production may make it difficult for the firm to identify individual contributions (Alchian and Demsetz 1972). However, differential rewards for group performance can be based on observable worker characteristics such as qualification or training. Jones and Kato (2004) find that the screening of team members by management improves the performance effect of teams. Screening requires additional monitoring (in order to know which workers to select) and, hence, provides valuable information about the team members' initial skills and abilities. This information can be used to reward workers differently for good team performance.

Alternatively, teamwork may result in higher efficiency wages for skilled workers. ${ }^{5}$ One can argue, in the style of Ramaswamy and Rowthorne (1991), that the 'damage potential' of the individual worker influences the efficiency wage paid to this worker. The employer will pay a higher efficiency wage to workers with a higher damage potential in order to reduce their incentive to inflict damage on production. As skilled workers play a crucial role in team production, they are likely to have a disproportionately high potential to disrupt teamwork. Moreover, it can be argued that team production is particularly associated with increased task complexity for skilled workers. Hence, it lowers the probability that a skilled worker is caught 
shirking. As a consequence, the firm has to increase skilled workers' wages to ensure their effort. Clearly, an efficiency wage explanation pressuposes that the probability of detecting shirking is only reduced and does not drop to zero under team production. While teamwork might make an 'objective' assessment of individual effort difficult, the employer can use subjective evaluations by superiors to assess individual worker effort. ${ }^{6}$ Findings by Heywood et al. (2007) support the notion that subjective performance evaluations are a strategic response to the incentive problems associated with teamwork. The presence of self-managed teams is positively associated with both the use of performance appraisals by supervisors and the share of workers who are subject to performance appraisals. Such performance appraisals ensure a minimum probability of detecting shirking on the job. ${ }^{7}$

Altogether, we anticipate that firms using self-managed teams exhibit greater wage dispersion among blue-collar workers because these firms provide disproportionately higher incentives to skilled team members. The rise in intra-firm wage dispersion is reinforced if teamwork results in lower wages for unskilled blue-collar workers. As outlined above, teamwork may entail an increased specialization of skilled and unskilled workers. Such a specialization leaves only routine and menial tasks for unskilled workers, reducing the necessity to pay high wages to these workers. However, one might argue that even unskilled workers could gain from teamwork. If skilled team members provide expertise and help, the productivity of their unskilled colleagues may rise, resulting in higher unskilled wages. Yet, as long as skilled workers play a disproportionate role in the success of teams, skilled wages will rise more than unskilled wages. Thus, even in this situation, teamwork will be associated with increased intra-firm wage inequality between skilled and unskilled blue-collar workers.

This hypothesis contrasts with the view that teamwork requires a more egalitarian wage structure. According to the 'fair wage-effort' hypothesis by Akerlof and Yellen (1990), workers withdraw effort if their actual wage falls short of the wage the workers themselves consider as fair. Akerlof and Yellen postulate that the fair wage is determined as a weighted 
average of the wages of a reference group. Levine (1991) puts foreward this argument by stressing that particularly team production gives rise to social comparisons as it increases social interactions among workers. Therefore, in firms where team production is important a more egalitarian wage structure might result in higher group cohesiveness and increased productivity. However, even if fairness considerations play an important role in team production, this may not necessarily imply that workers prefer an egalitarian wage structure. Frey et al. (2004) emphasize that workers are often not only concerned with the outcomes, but also with the ways these outcomes are determined. They argue that procedural justice is a

source of worker utility. ${ }^{8}$ Hence, team members may accept unequal wages if the process of determining pay accords with procedural fairness norms. Differential rewards based on skills are likely to accord with such norms. This may be particularly the case in a situation where skilled workers help low-skilled workers improve their performance.

While we anticipate a positive relationship between self-managed production teams and intra-firm wage dispersion, we also stress that moderating factors are very likely to play a role in the strength of this relationship. In what follows, we hypothesize that teamwork interacts with employer-provided further training, production technology, establishment age and industrial relations.

\subsection{The Moderating Role of Employer-Provided Further Training}

Empirical studies have shown a strong, albeit not perfect link, between the use of selfmanaged teams and employer-provided further training (Black and Lynch 1998, Gerlach and Jirjahn 2001). This confirms the notion that teamwork is associated with increased skill requirements. Workers perform a broader set of tasks, and delegating decisions to them presupposes that they comprehend important elements of the production process. Social interaction is greater, and workers need to be trained in social competences.

Previous research has also confirmed that not all workers are equally likely to receive 
training. Skilled workers receive a higher amount of training. Employer-provided further training appears to be complementary to the workers' initial skills. Our discussion suggests that teamwork will increase the training gap between unskilled and skilled workers. As skilled workers play a crucial role in the performance of teams, they will receive an even more disproportionate amount of training under team production. This reinforces their crucial role and widens the inequality among skilled and unskilled team members. Altogether, we hypothesize that team production will have an even stronger impact on intra-firm wage dispersion among blue-collar workers when it is coupled with employer-provided further training. Or put slightly differently, teamwork and employer-provided further training should interact positively with respect to intra-firm wage dispersion.

\subsection{The Moderating Role of Production Technology}

The vintage of production technology is also likely to play a moderating role. New production technologies partially substitute for routine tasks. This leads to even more menial tasks for unskilled team members and helps skilled team members to even more focus on complex tasks. Moreover, more complicated production technologies require skilled workers with increased responsibility to run and operate these technologies. ${ }^{9}$ This even further strengthens the role skilled workers play in team production. Hence, the effect of self-managed teams on intra-firm wage dispersion among blue-collar workers is likely to be stronger when team production is coupled a with a production technology of the most recent vintage.

This line of reasoning has also implications for earlier studies on technological change. Doms et al. (1997) found that new production technologies have little influence on the skill requirements for production workers. However, the effects of technological change may depend on the organization of work. New production technologies may have no or even a deskilling effect on blue-collar workers when there is no reorganization of work and production workers have little scope for decision making. Only new technologies coupled 
with increased responsibilites and expanded involvment in decision making are likely to increase the skill requirements for blue-collar workers.

\subsection{The Moderating Role of Establishment Age}

Empirical findings by Ichniowski and Shaw (1995) indicate that older firms are less likely to adopt innovative HPW systems. We hypothesize that even if an older firm implements team production, it may face difficulties in adopting a complementary pay policy. First, changes in personnel management policies require organizational learning processes. As learning is predominantly cumulative and closely related the firm's previous experiences (Teece et al. 1994), older firms with a more bureaucratic organization and established routines and heuristics are less likely to find new policies they are not familiar with. Second, worker resistance may cause higher adjustment costs (Milgrom and Roberts 1995). Our previous discussion suggests that unskilled workers may lose from teamwork. They are likely to have more opportunites to resist a change in pay policy if the firm is older. Seniority rights may protect uncooperative workers from sanctions. Altogether, we anticipate a positive effect of teamwork on wage dispersion in younger firms and a less clear effect in older firms.

\subsection{The Moderating Role of Industrial Relations}

German industrial relations are characterized by a dual structure of employee representation with both works councils and unions (Hubler and Jirjahn 2003). Collective agreements are usually negotiated between unions and employers' associations on a broad industrial level. They regulate wage rates and general aspects of the employment contract such as working hours. Typically, establishments are covered by an agreement if they are members of an employers' association. ${ }^{10}$ The agreement can be extended also to non-member establishments by the Federal Ministry of Labor. Covered establishments usually pay the negotiated wage rate to both union and non-union members (Fitzenberger and Franz 1999).

Studies from Anglo-Saxon countries show that union contracts reduce wage dispersion 
among workers covered by these contracts (Card et al. 2004, Freeman 1980). Yet, it is not clear if this relationship holds in countries with higher degrees of centralization in collective bargaining. Collective agreements negotiated by unions and employers' associations define minimum standards. Covered firms are free to pay wages above the level specified by an agreement. The resulting wage drift may diminish the equalizing effect of collective agreements. While collective bargaining at the sectoral level tends to reduce wage dispersion, this effect can be offset by wage supplements paid unilaterally by the firms (Cardoso and Portugal 2005, Dell' Aringa and Pagani 2007, Hartog et al. 2002). This line of reasoning presupposes that firms pay disproportionate wage supplements to skilled workers.

However, employers may prefer to reduce the wages of their unskilled employees. In that case, covered firms exhibit downward wage rigidity as the minimum wages set by collective bargaining agreements are binding (Kahn 2000). Indeed, survey evidence provided by Franz and Pfeiffer (2006) confirms that collective agreements are an important reason for downward rigidity of low-skilled wages in Germany. Hence, collective bargaining coverage may be associated with lower intra-firm wage dispersion if employers want to cut the wages of their low-skilled workers. This brings us to an issue which is largely neglected in the empirical literature on collective bargaining and wage dispersion. Insofar employers differ in their propensity to reduce the wages of their low-skilled employees, there will be no uniform relationship between collective bargaining coverage and intra-firm wage dispersion. The relationship will vary according to circumstances and type of firm. ${ }^{11}$ We hypothesize that collective bargaining coverage under certain circumstances may interact with teamwork.

If teamwork predominantly requires higher wages for skilled workers, there will be little interaction between collective bargaining coverage and the use of self-managed teams. As collective agreements only define a lower bound on wages, firms using self-managed teams are free to pay wage supplements to high-skilled team members. Hence, the relationship between teamwork and intra-firm wage dispersion should not differ between 
covered and uncovered firms. However, collective bargaining coverage may negatively interact with the use of self-managed teams if teamwork requires both higher wages for skilled team members and substantially lower wages for unskilled team members. Uncovered firms can realize both higher skilled wages and lower unskilled wages. In contrast, covered establishments can only realize higher wages for skilled team members. The lower bound on wages set by collective agreements is likely to prevent a downward adjustment in unskilled wages. Thus, teamwork will have a less strong effect on intra-firm wage dispersion if the firm is covered by a collective agreement. Such a negative interaction effect might explain the finding by Gerlach et al. (1998) that establishments with self-managed teams are more likely to escape collective bargaining.

German works councils provide a highly developed mechanism for establishment level codetermination. Their rights are laid down in the Works Constitution Act. The law states that councils shall be elected by the workforce of establishments with five or more employees. However, their creation depends on the initiative of the workforce. Hence, councils are not present in all eligible establishments. Works councils have functions that are distinct from those of unions. They are an institution designed to foster communication between employees and management and to build trustful and cooperative industrial relations within establishments (Smith 1991, Freeman and Lazear 1995). The intended purpose of this institution is to create joint establishment surplus rather than to redistribute it. Wage negotiations between councils and management are not allowed.

However, councils can use their codetermination rights to obtain employer concessions on issues where they have no legal powers. If employer and works council fail to reach an agreement in informal wage negotiations, the council can threaten to be uncooperative in areas where its consent is necessary. Empirical studies routinely confirm that works councils have an influence on wages. Most importantly, there is evidence that works councils are associated with reduced intra-firm wage dispersion (Hubler and Meyer 2001). 
Moreover, councils appear to have a stronger productivity-enhancing effect in establishments with low intra-firm wage dispersion (Jirjahn and Kraft 2007). These findings fit the notion that wage inequality undermines the functioning and bargaining strength of works councils. Hence, one may hypothesize that works councils will oppose the rising wage inequality associated with team production. The use of self-managed teams should have a less strong impact on intra-firm wage dispersion when a works council is present.

\section{Previous Empirical Studies}

While the link between firm performance and HPW practices such as teams has been widely examined, there is only a small number of studies on the wage effects of teamwork (see Handel and Levine 2004 for a review). In particular, there is very little research on the relationship between teams and the wage structure within establishments. Using employee data, Bailey et al. (2001) provide descriptive statistics for the US. They find that there is more variation in earnings among workers participating in self-managed teams than among workers not participating in teams. However, Bailey et al. (2001) do not address the question whether teamwork increases wage dispersion within or between establishments. Based on linked employer-employee data, Bauer and Bender (2001) show for Germany that the introduction of self-managed teams is associated with increased wage dispersion within establishments. ${ }^{12}$ The introduction of teams increases the differential between the $80^{\text {th }}$ and the $20^{\text {th }}$ and the $50^{\text {th }}$ and the $20^{\text {th }}$ percentile of the intra-firm wage distribution. These important findings raise the question which types of workers are affected by teamwork.

Some studies use US establishment data to examine the link between teams and wages for different occupational groups within establishments. These studies consider production workers as a homogeneous group. Capelli (1996) finds that self-managed teams are associated with both higher average pay for production workers and higher average pay for supervisors. The results are largely confirmed by Capelli and Carter (2000). However, Black et al. (2004), 
working with the same data, find a positive association between self-managed teams and the average wage of supervisors only in unionized but not in nonunionized establishments. Moreover, they obtain the result that self-managed teams have no influence on the average pay for production workers. A study by Osterman (2000) shows even a negative link between teams and the average wage of workers directly involved in production. Altogether, the few available studies provide mixed results on the relationship between self-managed teams and the wages of production workers. One reason for these mixed findings may be that production workers are no homogeneous group. The relationship between teams and wages may differ between unskilled and skilled production workers. Moreover, the relationship may vary according to circumstances and the type of establishment.

Osterman (2006) examines the link between HPW practices and wage inequality among blue-collar workers directly involved in production. Using an index of various HPW practices, he finds that HPW practices have no influence on within-establishment wage disperion. ${ }^{13}$ However, as indicated by his earlier study (Osterman 2000), HPW practices can differ in their wage effects. Hence, it appears to be interesting to examine the wage effects of specific HPW practices such as teamwork.

Finally, Hamilton et al. (2003) report in their case study of a garment plant that while most sewers experienced a pay increase after joining a team, sewers at the top end of the pay distribution experienced a reduction in hourly pay under teamwork. This raises the question if the findings of this case study carry over to other circumstances and types of establishments. For example, as noted by Hamilton et al. (2003: 494ff) themselves, the presence of a union might have influenced the link between team production and wages.

As our brief review makes clear, the empirical literature reports mixed results on the relationship between teams and wage dispersion within establishments. Moreover, the literature on the wage effects of teams is essentially silent on the role of moderating factors. Hence, more evidence is certainly warranted. 


\section{Data and Variables}

\subsection{Data Set}

The data are drawn from the fourth, 1997, wave of the Hanover Panel (Gerlach et al. 2003). The Hanover Panel is a four-wave panel with data from manufacturing establishments in the federal state of Lower Saxony, a highly industrial area of Germany. The population of the survey consists of all manufacturing establishments with five or more employees. The sample is stratified according to establishment size and industry, with an oversampling of larger establishments. The sample was designed in such a way that a sufficient number of cell entries remained after four waves despite sample attrition. Observations were drawn randomly for each cell. The Hanover Panel was financed by the Volkswagen Foundation. Interviews were conducted by Infratest Sozialforschung, a professional survey and opinion institute. The data were collected on the basis of a questionnaire in personal interviews with the owner, top manager or head of the personnel department. In the first wave (fall 1994), 51 percent of the establishments in the sample agreed to participate. In spite of this non-response rate the data are representative of the manufacturing establishments in Lower Saxony in 1994 and in the subsequent years. Apart from basic information on the establishment additional topics were covered in successive waves. The fourth wave contains information on intra-firm wage dispersion among blue-collar workers. ${ }^{14}$

\subsection{Dependent Variable}

Table 1 shows the definition of the variables and their descriptive statistics. ${ }^{15}$ The dependent variable is the percentage difference between the highest effective hourly wage of a skilled blue-collar worker and the lowest effective hourly wage of an unskilled blue-collar worker. On average, the difference is about 37 percent. The median equals 30 percent. Skilled bluecollar workers are those blue-collar workers who have completed an apprenticeship training after graduating from a general secondary school. The distinctive feature of the German 
apprenticeship system is its dual structure (Winkelmann 1996). Apprentices typically attend publicly-funded vocational part-time schools 1-2 days a week in addition to working and learning at the workplace. Employers bear the cost of within-firm training voluntarily. The apprenticeship training ends after 2-3.5 years. Detailed curricula are developed in cooperation with state institutions, employer organizations and trade unions. Regionally organized chambers of commerce and chambers of crafts coordinate and administer the programs.

\subsection{Explanatory Variables}

The data provide a rich set of explanatory variables. Controlling for a variety of establishment characteristics is important as wages are not simply determined by the demand and supply conditions in the external labor market. Employers pursue their own remuneration policy. Groshen (1991) provides evidence that wages vary substantially across establishments. We examine the factors influencing the distribution of wages within establishments and, hence, stress that also the intra-firm wage inequality between given skill groups can systematically differ across employers.

The explanatory variable of primary interest is a dichotomous indicator of whether blue-collar workers are organized in production teams with expanded involvement in decision-making and increased responsibility. 40 percent of establishments reported that their blue-collar workers are organized in self-managed teams. Based on our theoretical considerations, we anticipate that the use of self-managed teams is positively associated with intra-firm wage inequality between skilled and unskilled blue-collar workers. However, our hypotheses also imply that moderating factors may play a role in the relationship between self-managed teams and wage dispersion. We anticipate that team production interacts positively with state-of-the-art technologies and employer-provided further training, and negatively with works council presence, collective bargaining coverage and establishment age. The variable capturing technology is a dummy equal to 1 if the production technology is 
of the most recent vintage. Employer-provided further training is captured by training expenditures per employee. Furthermore, we include dummy variables for works council incidence, collective bargaining coverage and establishments founded before 1960 .

The interaction of works council presence with collective bargaining coverage is also taken into account. Hubler and Jirjahn (2003) show that works councils have a less strong influence on the average wage level of establishments covered by a collective bargaining agreement. This indicates that centralized collective bargaining reduces distributional conflicts on the establishment level. Rent-seeking activies of works councils are more restricted in covered establishments. Applying this line of reasoning to intra-firm wage dispersion, it can be expected that works councils will have a less strong influence on the structure of wages if the establishment is covered by a collective bargaining agreement.

The managerial environment is captured by a dummy equal to 1 if the executive managers of the establishment have a profit sharing plan. Bandiera et al. (2007) and Groves et al. (1994) show that managerial profit sharing is associated with increased intra-firm wage dispersion among workers in lower tiers of hierarchy. Implementing differential incentives for skilled and unskilled workers can be personally costly to managers. To avoid contentions with the workers and dissatisfaction among those not receiving higher pay, managers have to spend effort to ensure that increased wage inequality accords with procedural fairness norms. Managerial profit sharing provides a positive inducement to bear the personal costs involved in implementing efficiency wages or performance evaluation systems. Moreover, profit sharing may induce managers to target their effort and support to skilled workers, implying a higher productivity differential and, hence, increased wage inequality between skilled and unskilled workers.

We also include a variable for the interaction of managerial profit sharing and works council presence. Previous research has shown that the effect of managerial profit sharing on firm performance depends on the presence of a works council (Jirjahn 2003). Managerial 
profit sharing and works council incidence may also interact with respect to intra-firm wage dispersion. If wage inequality undermines the functioning and bargaining strength of works councils, they are likely to oppose management attempts to provide differential rewards. Hence, managerial profit sharing may have a less strong effect on wage dispersion if a works council is present.

Furthermore, the data provide some information on the method of pay for employees other than executives. We include a dummy equal to 1 if the establishment uses piece rates in its production department. While there exist a variety of pay-for-performance schemes, piece rates are an incentive scheme quite often analyzed in the literature (for a review see Heywood and Jirjahn 2006). Several studies confirm a positive association between piece rates and wage dispersion (Lazear 2000, Seiler 1984, Shearer 2004). Moreover, a dummy for nonmanagerial profit sharing is included. There is an ongoing discussion whether profit sharing is a supplement or substitute to workers' base pay (Kruse 1993). If the link between profit sharing and base pay differs between skilled and unskilled workers, profit sharing might have an effect on our measure of intra-firm wage dispersion.

Studies by Black and Strahan (2001), Guadalupe (2007) and Wozniak (2007) show that product market competition has an influence on the structure of wages within industries. Competition may also influence wage dispersion within establishments. However, from a theoretical view point, the effect is ambiguous. On the one hand, product market competition may induce managers to improve the establishment's competiveness by reducing unskilled wages and providing stronger incentives for skilled workers. This implies a positive link between competition and intra-firm wage dispersion. On the other hand, higher product market competition decreases non-competitive rents. If skilled workers have stronger bargaining power than unskilled workers, they will capture a larger share of the noncompetitive rents associated with low competition. Hence, increased product market competition may involve larger wage losses for skilled workers than for unskilled workers. 
This implies a negative link between product market competition and intra-firm wage disperision. We capture the nature of product market competition by the sales of the the six largest companies as a share of total sales in the industry. Official German statistics on industrial concentration are matched to thirty-two industrial sectors identified by the survey. Three broader defined industry dummies are included to account for variations in the nature of what is being produced.

We also control for the use of shift work. Shift work is typically perceived as creating troublesome problems for the health, family life and on-the-job-safety of employees. Kostiuk (1990) shows that shift workers receive higher wages than other workers, a result consistent with the theory of compensating differentials. Hamermesh (1999) finds that unskilled workers are disproprotionately on night shifts. ${ }^{16}$ This confirms that shift work is an inferior schedule. For workers with a low earnings potential, it is an opportunity to supplement their earnings. However, if the production technology to some extent requires both unskilled and skilled workers, the employer must ensure that skilled workers participate in shift work. As shift work is an inferior schedule, skilled workers will require a higher compensating differential than unskilled workers in order for them to accept shift work. Hence, this schedule is likely to be associated with increased intra-firm wage inequality between skilled and unskilled bluecollar workers.

While numerous studies have documented an employer-size wage premium (e.g. Brown and Medoff 1989), the link between employer size and the (intra-firm) distribution of wages has been paid far less attention. Lluis (2007) finds that the returns to education do not depend on employer size in Canada, while they increase with employer size in the United States. Based on data from Taiwanese manufacturing firms, Tsou et al. (2006) show that the employer-size wage premium is larger for skilled workers than for unskilled workers. In light of these studies, we hypothesize that large-scale production is associated with increased intrafirm wage dispersion. Oi (1983) argues that firm-specific human capital accumulation occurs 
disporportionately at larger firms. Hence, if primarily skilled workers accumulate specific human capital, wage inequality between skilled and unskilled blue-collar workers will be higher in larger firms. The scale of production is taken into account by the number of employees in the establishment. An additional indicator is whether the establishment is a single establishment or part of a multi-establishment firm. Being part of a multi-establishment firm may create a large-scale production network.

Finally, we include variables for the employment shares of all blue-collar workers, skilled blue-collar workers, temporary workers, university graduates and women. Note that these controls help to interpret the empirical results (Osterman 2006). If the estimates show a link between teamwork and intra-firm wage dispersion, controlling for the structure of the workforce rules out a story in which team production leads establishments to demand more skilled workers and the need to acquire a larger share of skilled workers influences the wages paid by the establishment. The association between teamwork and wage dispersion will be rather driven by the specific responsibilites and tasks of skilled and unskilled team members within the establishment. As outlined in the the theoretical section, these responsibilities and tasks are likely to involve specific incentive issues resulting in higher skilled wages and possibly lower unskilled wages.

\section{Empirical Results}

Wages are usually not normally distributed but skewed and outliers often pose severe problems. Therefore, we use median regressions which reduce the influence of the residuals. This method minimizes the median of ordered squares of residuals. The procedure forms initial estimates from a weighted least squares of absolute residuals. Then the method applied estimates the median by taking the raw sum of absolute deviations around the unconditional median. The estimated coefficients minimize this function. The procedure estimates a constant and parameters that predict the median. The standard errors are computed from the 
estimated weighted variance-covariance matrix of the coefficients.

Table 2 presents the regression results. The estimates shown in the first column do not take into account interaction effects while interaction variables are included in the estimates shown in the second column. Many of the control variables take statistically significant coefficients of the expected sign. Managerial profit sharing is associated with increased intrafirm wage dispersion between skilled and unskilled blue-collar workers. This association is stronger if no works council is present. Shift work and piece rates are also positive covariates of wage dispersion. Competition (low product market concentration) is associated with reduced wage dispersion. Further, the scale of production plays a role. Wage dispersion is higher in larger establishments and in establishments that are part of a multi-establishment firm. Moreover, the results on the variables for the structure of the workforce reveal an interesting pattern. The shares of women and temporary workers are negative covariates and the share of skilled blue-collar workers is a positive covariate of wage dispersion.

Turning to the variable of primary interest, the regression in the first column shows that the use of self-managed teams is positively related to intra-firm wage inequality between skilled and unskilled blue-collar workers. This statistically significant result confirms our basic hypothesis. Team production involves an increased specialization of skilled and unskilled blue-collar workers resulting in increased wage dispersion. While skilled blue-collar workers have an increased responsibility for complex tasks, unskilled blue-collar workers may specialize in menial and routine tasks. The magnitude and significance of the coefficient on teams increases when including the interaction variables in the second regression. Most of the interaction variables take statistically significant coefficients of the expected sign.

In order to interpret the results, let us first consider an uncovered establishment that does not provide further training. Moreover, let us assume that the establishment is founded after 1960 but does not use a state-of-the-art production technology. In this establishment, the use of self-managed teams is associated with a more than 5 percentage point higher wage 
inequality between skilled and unskilled blue-collar workers. Taking this situation as a benchmark, we will now successively discuss the influence of each moderating variable.

The coefficient on employer-provided further training is significantly positive. This can be explained by the training gap between skilled and unskilled workers. If employerprovided further training is complementary to the workers' initial skills, qualified workers will receive a higher amount of training. This in turn widens the wage inequality between skilled and unskilled workers. Moreover, the coefficient on the interaction of teams and employer-provided further training is significantly positive. If skilled workers play a crucial role in team production, the use of self-managed teams results in an even larger training gap. This reinforces the crucial role played by skilled team members resulting in even higher wage inequality. Hence, compared to the benchmark, team production has a stronger effect on intrafirm wage disperion when coupled with employer-provided further training. Let us consider an establishment where the per head expenditure on further training amounts to 200 German marks. This is roughly the average amount in our sample. In this establishment, the use of self-managed teams is associated with an almost 7 percentage point higher wage dispersion between skilled and unskilled blue-collar workers. ${ }^{17}$

The coefficient on technologies of the most recent vintage is signficantly negative while the interaction of teamwork and technologies of the most recent vintage is significantly positive. This suggests that technological change has a rather deskilling effect on blue-collar workers when it is not coupled with increased responsibilities and expanded involvement in decision making. However, a modern production technology reinforces the skill-biased effect of team production. New production technologies may substitute for routine tasks done by unskilled team members and help skilled team members to even more focus on difficult tasks. Thus, compared to our benchmark, the effect of teamwork on wage dispersion is stronger in establishments with a state-of-the-art production technology. In these establishments, the use of self-managed teams is associated with an almost 12 percentage point higher wage 
dispersion among blue-collar workers.

The coefficient on establishment age is statistically insignificant while the interaction of establishment age and team production is significantly negative. The negative interaction effect fits the hypothesis that older establishments with fixed routines and a more bureaucratic organization face difficulties in finding new pay policies that complement team production. The coefficient on the interaction variable is roughly of the same magnitude (but of opposite sign) as that for the basic teamwork variable. As a consequence, compared to the benchmark, the null hypothesis that team production has no influence on wage dispersion in establishments founded before 1960 cannot be rejected. Team production increases wage inequality in older establishments only if it coupled with employer-provided further training or a state-of-the-art technology.

While the coefficient on collective bargaining coverage is statistically insignificant, the interaction of collective bargaining coverage and team production takes a negative and significant coefficient. This pattern of results implies that the coverage by industry-level bargaining is not associated with a compressed wage structure when there is no teamwork. The minimum standards set by collective bargaining agreements appear to be less likely to be binding in establishments without team production. Moreover, while industry-level bargaining may tend to reduce wage dispersion, this effect can be offset by wage supplements for skilled workers paid unilaterally by the establishments. However, the minimum standards defined in collective bargaining agreements are more likely to be binding if there is team production. As outlined in the theoretical section, team production may not only require higher skilled wages but also lower unskilled wages. As collective bargaining agreements prevents employers from cutting unskilled wages, collective bargaining coverage leads to a compressed wage structure when there is team production. Or put slightly differently, team production has a less strong or even very small influence on wage dispersion in covered establishments. The coefficient on the interaction of collective bargaining coverage and teams is roughly of the same magnitude 
(but of opposite sign) as that for the the basic team production variable. Hence, compared to the benchmark, the null hypothesis that team production has no effect on wage dispersion in covered establishments cannot be rejected. However, team production increases wage inequality even in a covered establishment if it is coupled with employer-provided further training or a production technology of the most recent vintage.

Finally, the presence of a works council is associated with lower wage inequality between skilled and unskilled blue-collar workers. The negative association is less strong if the establishment is covered by a collective bargaining agreement. This suggests that the coverage by industry-level bargaining reduces distributional conflicts and rent-seeking activities on the establishment level. However, the estimates show no statistically significant interaction of works councils and teamwork. Hence, the hypothesis that works councils oppose the rising wage inequality associated with teamwork is not supported. One explanation could be that there might be a second effect of establishment-level codetermination working in the opposite direction. Works councils provide a mechanism for building trust and negotiating change on the establishment level. This may contribute to increased flexibility in adjusting wages. This second effect can offset the first one.

\section{Concluding Remarks}

Blue-collar workers are often viewed as a homogeneous group of low-skilled employees. However, blue-collar workers are those workers who are directly involved in skill-biased team production. Hence, it is to be important to distinguish between skilled and unskilled blue-collar workers. Our results show that the use of self-managed production teams is associated with increased intra-firm wage inequality between skilled and unskilled blue-collar workers. Moreover, we emphasize that moderating factors play an important role in the relationship between team production and intra-firm wage dispersion. The role of moderating factors has been paid little attention in studies on the wage effects of HPW practices. We find 
that the link between team production and intra-firm wage dispersion is stronger when the production technology is of the most recent vintage and the employer provides further training. Team production interacts negatively with establishment age and collective bargaining coverage. The estimates provide no evidence that teamwork interacts with the presence of a works council.

We end this paper with some speculative remarks and a suggestion for further research. The negative interaction of teamwork with collective bargaining coverage may shed light on recent changes of the wage structure in Germany. While wage inequality has been rising in the United States since the 1970s, Germany experienced an increase in wage dispersion only since the 1990s. In the 1990s, the share of establishments covered by collective bargaining agreements declined substantially. This decline in collective bargaining coverage implies that skill-biased organizational change was likely to have a stronger influence on economy-wide wage inequality in the 1990s. In earlier decades, the economywide wage effects of organizational change may have been less perceptible due to the higher density of collective bargaining coverage. There was a higher share of establishments where collective bargaining agrements prevented employers from adjusting the intra-firm wage structure to new modes of production. Exploring this hypothesis in more detail stands as important future research. 


\section{References}

Acemoglu, Daron. 2002. “Technical Change, Inequality and the Labor Market.” Journal of Economic Literature 40, pp. 7-72.

Acemoglu, Daron. 1999. "Changes in Unemployment and Wage Inequality: An Alternative Theory and Some Evidence.” American Economic Review 89, pp. 1259-78.

Addison, John, Claus Schnabel and Joachim Wagner. 2007. “The (Parlous) State of German Unions.” Journal of Labor Research 28, pp. 3-18.

Aghion, Philippe, Eve Caroli and Cecilia Garcia-Penalosa. 1999. "Inequality and Economic Growth: The Perspective of the New Growth Theories.” Journal of Economic Literature 37, pp. 1615-60.

Alchian, A. and H. Demsetz. 1972. "Production Costs, Information and Economic Organization.” American Economic Review 62, pp. 777-95.

Aoki, M. 1990. “The Participatory Generation of Information Rents and the Theory of the Firm.” In: M. Aoki, B. Gustafsson and O.E. Williamson, eds., The Firm as a Nexus of Treatises. Sage, Thousand Oaks, CA.

Autor, David H., Frank Levy and Richard J. Murane. 2003. "The Skill Content of Recent Technological Change.” Quarterly Journal of Economics 118, pp. 1297-338.

Akerlof, George and Janet Yellen. 1990. “The Fair Wage-Effort Hypothesis and Unemployment.” Quarterly Journal of Economics 105, pp. 255-83.

Bailey, Thomas, Peter Berg and Carola Sandy. 2001. "The Effect of High-Performance Work Practices on Employee Earnings in the Steel, Apparel, and Medical Electronics and Imaging Industries.” Industrial and Labor Relations Review 54, pp. 525-46.

Baker, G., M.J. Jensen and K.J. Murphy. 1988. “Compensation and Incentives: Practice vs. Theory.” Journal of Finance 18, pp. 593-616.

Bandiera, Oriana, Iwan Barankay and Imran Rasul. 2007. "Incentives for Managers and Inequality Among Workers: Evidence from a Firm-Level Experiment.” Quarterly Journal of Economics 122, pp. 729-73.

Bauer, Thomas and Stefan Bender. 2001. "Flexible Work Systems and the Structure of Wages: Evidence from Matched Employer-Employee Data.” IZA Discussion Paper No. 353, Bonn. 
Bell, David and Robert A. Hart. 1999. “Unpaid Work.” Economica 66, pp. 271-90.

Berman, Eli, John Bound and Stephen Machin. 1998. "Implications of Skill-Biased Technological Change: International Evidence.” Quarterly Journal of Economics 113, pp. 1245-79.

Black, Sandra E. and Lisa M. Lynch. 1998. "Beyond the Incidence of Employer Provided Training.” Industrial and Labor Relations Review 52, pp. 64-81.

Black, Sandra E., Lisa M. Lynch and Anya Krivelyova. 2004. "How Workers Fare When Employers Innovate.” Industrial Relations 43, pp. 44-66.

Black, Sandra E. and Philip Strahan. 2001. "The Division of Spoils: Rent-Sharing and Discrimination in a Regulated Industry.” American Economic Review 91, pp. 814-31.

Bresnahan, Timothy F., Erik Brynjolfsson and Lorin M. Hitt. 2002. "Information Technology, Workplace Organization, and the Demand for Skilled Labor: Firm-level Evidence.” Quarterly Journal of Economics 117, pp. 329-76.

Brown, C. and J. Medoff. 1989. “The Employer-Size Wage Effect.” Journal of Political Economy 97, pp. 1027-59.

Capelli, Peter. 1996. "Technology and Skill Requirements: Implications for Establishment Wage Structure.” New England Economic Review (May-June), pp. 138-54.

Capelli, Peter and William Carter. 2000. “Computers, Work Organization, and Wage Outcomes.” NBER Working Paper No. 7987.

Card, David, Thomas Lemieux and W. Craig Riddell. 2004. “Unions and Wage Inequality.” Journal of Labor Research 25, pp. 519-62.

Cardoso, Ana Rute and Pedro Portugal. 2005. "Contractual Wages and the Wage Cushion under Different Bargaining Settings.” Journal of Labor Economics 23, pp. 875-900.

Caroli, Eve and John Van Reenen. 2001. "Skill-biased Organizational Change? Evidence from a Panel of British and French Establishments.” Quarterly Journal of Economics 116, 1449-92.

Dell’ Aringa, Carlo and Laura Pagani. 2007. “Collective Bargaining and Wage Dispersion in Europe.” British Journal of Industrial Relations 45, pp. 29-54.

Dolan, Paul, Richard Edlin, Aki Tsuchiya and Allan Wailoo. 2007. "It Ain’t What You Do, It's the Way That You Do It: Characteristics of Procedural Justice and Their Importance in Social 
Decision-Making.” Journal of Economic Behavior and Organization 64, pp. 157-70.

Doms, Mark, Timothy Dunne and Kenneth R. Troske. 1997. "Workers, Wages and Technology." Quarterly Journal of Economics 112, pp. 253-90.

Falk, Armin and Andrea Ichino. 2006. "Clean Evidence on Peer Effects.” Journal of Labor Economics 24, pp. 39-57.

Fitzenberger, Bernd and Wolfgang Franz. 1999. "Industry-level Wage Bargaining: A Partial Rehabilitation - The German Experience.” Scottish Journal of Political Economy 46, pp. 437-57.

Foss, Nicolai J. 2001. "Leadership, Beliefs and Coordination: An Explorative Discussion.” Industrial and Corporate Change 10, pp. 357-88.

Franz, W. and F. Pfeiffer. 2006. “Reasons for Wage Rigidity in Germany.” Labour 20, pp. 255-84.

Freeman, Richard B. 1982. "Union Wage Practices and Wage Dispersion within Establishments.” Industrial and Labor Relations Review 36, 3-21.

Freeman, R.B. and L. F. Katz. 1995. "Introduction and Summary." In Differences and Changes in Wage Structures, edited by R. Freeman and L. Katz. University of Chicago Press, pp. 1-22.

Freeman, Richard B. and Edward P. Lazear. 1995. “An Economic Analysis of Works Councils.” In Works Councils - Consultation, Representation and Cooperation in Industrial Relations, edited by J. Rogers and W. Streeck, Chicago: University of Chicago Press, pp. 27-52.

Frey, Bruno, Matthias Benz and Alois Stutzer. 2004. "Introducing Procedural Utility: Not Only What, but Also How Matters.” Journal of Institutional and Theoretical Economics 160, pp. 377-401.

Galor, Oded and Omer Moav. 2000. “Ability-Biased Technological Transition, Wage Inequality and Economic Growth.” Quarterly Journal of Economics 115, pp. 469-497.

Garicano, Luis and Esteban Rossi-Hansberg. 2006. “Organization and Inequality in a Knowledge Economy.” Quarterly Journal of Economics 121, pp. 1383-435.

Gerlach, Knut, Olaf Hubler and Wolfgang Meyer. 2003. "The Hannover Firm Panel (HFP).” Schmollers Jahrbuch - Journal of Applied Social Science Studies 123, pp. 463-70.

Gerlach, Knut and Uwe Jirjahn. 2001. "Employer Provided Further Training: Evidence from German Establishment Data.” Schmollers Jahrbuch - Journal of Applied Social Science Studies 121, pp. $139-64$. 
Gerlach, K., K. Lehmann and W. Meyer. 1998. "Entwicklung der Tarifbindung im Verarbeitenden Gewerbe Niedersachsens.” In: K. Gerlach, O. Hubler and W. Meyer, eds., Okonomische Analysen betrieblicher Strukturen und Entwicklungen - Das Hannoveraner Firmenpanel, Frankfurt: Campus, pp. 30-50.

Gernandt, Johannes and Friedhelm Pfeiffer. 2006. "Rising Wage Inequality in Germany.” ZEW Discussion Paper No. 06-019, Mannheim.

Groshen, Erica L. 1991. "Five Reasons Why Wages Vary Among Employers.” Industrial Relations 30, pp. 350-81.

Groves, Theodore, Yongmiao Hong, John McMillan and Barry Naughton. 1994. “Autonomy and Incentives in Chinese State Enterprises.” Quarterly Journal of Economics 109, pp. 183-209.

Guadalupe, Maria. 2007. "Product Market Competition, Returns to Skill, and Wage Inequality.” Journal of Labor Economics 25, pp. 439-74.

Hamermesh, Daniel. 1999. “The Timing of Work Over Time.” Economic Journal 109, pp. 37-66.

Hamilton, Barton H., Jack A. Nickerson and Hideo Owan. 2003. "Team Incentives and Worker Heterogeneity: An Empirical Analysis of the Impact of Teams on Productivity and Participation.” Journal of Political Economy 111, 465-97.

Handel, Michael J. and David I. Levine. 2004. "Editors' Introduction: The Effects of New Work Practices on Workers.” Industrial Relations 43, pp. 1-43.

Hansen, Daniel G. 1997. “Worker Performance and Group Incentives.” Industrial and Labor Relations Review 51, pp. 37-49.

Hartog, Joop, Edwin Leuven and Coen Teulings. 2002. "Wages and the Bargaining Regime in a Corporatist Setting: the Netherlands.” European Journal of Political Economy 18, pp. 317-31.

Helper, Susan, David I. Levine and Elliot Bendoly. 2002. "Employee Involvement and Pay at US and Canadian Auto Suppliers.” Journal of Economics and Management Strategy 11, pp. 329-77.

Heywood, John S. and Uwe Jirjahn. 2006. "Performance Pay: Determinants and Consequences.” In Contemporary Issues in Industrial Relations. LERA Research Volume, edited by D. Lewin, Labor and Employment Relations Association: Champaign IL, pp. 149-88.

Heywood, John S. and Uwe Jirjahn. 2004. “Teams, Teamwork and Absence.” Scandinavian Journal 
of Economics 106, pp. 765-82.

Heywood, John S., Uwe Jirjahn and Xiangdong Wei. 2007. “Teamwork, Monitoring and Absence.” Working Paper, University of Hanover.

Hong, Lu, Scott E. Page and William J. Baumol. 2004. “Groups of Diverse Problem Solvers Can Outperform Groups of High-Ability Problems Solvers.” Proceedings of the National Academy of Sciences of the United States of America 101, pp. 16385-9.

Hubler, Olaf and Uwe Jirjahn. 2003. "Works Councils and Collective Bargaining in Germany: The Impact on Productivity and Wages.” Scottish Journal of Political Economy 50, pp. 1-21.

Hubler, Olaf and Wolfgang Meyer. 2001. "Industrial Relations and the Wage Differentials within Firms.” Schmollers Jahrbuch - Journal of Applied Social Science Studies 121, pp. 285-312.

Ichniowski, Casey and Kathryn Shaw. 1995. "Old Dogs and New Tricks: Determinants of the Adoption of Productivity-Enhancing Work Practices.” Brookings Papers on Economic Activity. Microeconomics, pp. 1-65.

Jirjahn, Uwe. 2007. “On the Determinants of Shift Work and Overtime Work: Evidence from German Establishment Data.” British Journal of Industrial Relations, Forthcoming.

Jirjahn, Uwe. 2003. "Executive Incentives, Works Councils and Firm Performance.” Schmollers Jahrbuch - Journal of Applied Social Science Studies 123, pp. 397-421.

Jirjahn, Uwe and Kornelius Kraft. 2007. "Intra-firm Wage Dispersion and Firm Performance - Is There a Uniform Relationship?” Kyklos 60, pp. 231-53.

Jones, Derek and Takao Kato. 2004. "The Effects of Employee Involvement on Firm Performance: Evidence from an Econometric Case Study.” Working Paper, Hamilton College, Clinton, NY.

Kahn, Lawrence M. 2000. "Wage Inequality, Collective Bargaining, and Relative Employment from 1985 to 1994: Evidence from Fifteen OECD Countries.” Review of Economics and Statistics 82, pp. 564-79.

Kochan, T., K. Bezrukova, R. Ely, S. Jackson, A. Joshi, K. Jehn, J. Leonard, D. Levine and D. Thomas. 2003. "The Effects of Diversity on Business Performance: Report of the Diversity Research Network.” Human Resource Management 42, pp. 3-21.

Kohn, Karsten. 2006. "Rising Wage Dispersion, After All! The German Wage Structure at the Turn of 
the Century.” ZEW Discussion Paper No. 06-031, Mannheim.

Kostiuk, P. 1990. “Compensating Differentials for Shift Work.” Journal of Political Economy 98, pp. 1054-75.

Kremer, Michael and Eric Maskin. 1996. "Wage Inequality and Segregation by Skill.” NBER Working Paper No. 5718, Cambridge, MA.

Kruse, Douglas. 1993. Profit Sharing. Does It Make a Difference? Kalamazoo, MI: Upjohn Institute.

Lazear, E.P. 2000. “Performance Pay and Productivity.” American Economic Review 71, pp. 1346-61.

Lazear, E.P. 1999. “Globalization and the Market for Teammates.” Economic Journal 109, C15-C40.

Levine, David I. 1991. “Cohesiveness, Productivity, and Wage Dispersion.” Journal of Economic Behavior and Organization 15, pp. 237-55.

Lluis, Stephanie. 2007. "The Structure of Wages by Firm Size: A Comparison of Canada and the United States.” Working Paper, University of Waterloo.

Mas, Alexandre and Enrico Moretti. 2006. “Peers at Work.” NBER Working Paper No. 12508.

Mello, A. S. and M.E. Ruckes. 2006. “Team Composition.” Journal of Business 79, pp. 1019-39.

Milgrom, Paul and John Roberts. 1995. "Continuous Adjustment and Fundamental Change in Business Strategy and Organization.” In Horst Siebert, ed., Trends in Business Organization: Do Participation and Cooperation Increase Competitiveness? Tübingen: Mohr, pp. 231-58.

Moller, Joachim. 2005. “Die Entwicklung der Lohnspreizung in West- und Ostdeutschland.” In: Lutz Bellmann, Olaf Hubler, Wolfgang Meyer and Gesine Stephan, eds., Institutionen, Loehne und Beschaeftigung. Nuernberg: BeitragAB, pp. 47-63.

Oi, Walter. 1983. “The Fixed Costs of Specialized Labor.” In The Measurement of Labor Cost, edited by Jack Triplett, University of Chicago Press.

Osterman, Paul. 2006. "The Wage Effects of High Performance Work Organizations in Manufacturing.” Industrial and Labor Relations Review 59, pp. 187-204.

Osterman, Paul. 2000. "Work Reorganization in an Era of Restructuring: Trends in Diffusion and Effects of Employee Welfare.” Industrial and Labor Relations Review 53, pp. 179-96.

Osterman, Paul. 1994. “How Common Is Workplace Transformation and Who Adopts It?” Industrial and Labor Relations Review 47, pp. 173-88. 
Pil, Frits K. and John P. MacDuffie. 1996. “The Adoption of High-Involvement Work Practices.” Industrial Relations 35, pp. 423-55.

Prat, A. 2002. “Should a Team Be Homogeneous?” European Economic Review 46, pp. 1187-207.

Ramaswamy, Ramana and Robert E. Rowthorn. 1991. "Efficiency Wages and Wage Dispersion,” Economica 58, pp. 501-14.

Seiler, Eric. 1984. "Piece Rates vs. Time Rates: The Effect of Incentives on Earnings.” Review of Economics and Statistics 60, pp. 363-76.

Shapiro, C. and J.E. Stiglitz. 1984. "Equilibrium Unemployment as a Worker Discipline Device.” American Economic Review 74, pp. 107-29.

Shearer, Bruce. 2004. "Piece Rates, Fixed Wages and Incentives: Evidence from a Field Experiment.” Review of Economic Studies 71, pp. 513-34.

Smith, Stephen C. 1991. “On the Economic Rational for Codetermination Law.” Journal of Economic Behavior and Organization 12, pp. 261-81.

Stephan, Gesine and Knut Gerlach. 2005. "Wage Settlements and Wage Setting: Results from a Multilevel Model.” Applied Economics 37, pp. 2297-306.

Teece, David J., Richard Rumelt, Giovanni Dosi and Sidney Winter. 1994. “Understanding Corporate Coherence: Theory and Evidence.” Journal of Economic Behavior and Organization 23, pp. 1-30.

Thesmar, David and Mathias Thoenig. 2000. "Creative Destruction and Firm Organization Choice.” Quarterly Journal of Economics 115, pp. 1201-37.

Tsou, M.W., J.T. Liu and C.J. Huang. 2006. "Export Activity, Firm Size and Wage Structure: Evidence from Taiwanese Manufacturing Firms.” Asian Economic Journal 20, pp. 333-54.

Winkelmann, Rainer. 1996. “Employment Prospects and Skill Acquisition of Apprenticeship-Trained Workers in Germany.” Industrial and Labor Relations Review 49, pp. 658-72.

Winship, C. and L. Radbill. 1994. "Sampling Weights and Regression Results.” Sociological Methods and Research 39, pp. 230-57.

Winter, Eyal. 2004. “Incentives and Discrimination.” American Economic Review 94, pp. 764-73.

Wozniak, Abigail K. 2007. "Product Markets and Paychecks: Deregulation's Effect on the Compensation Structure in Banking.” Industrial and Labor Relations Review 60, pp. 246-67. 
Table 1: Variable Definition and Descriptive Statistics $(N=499)$

\begin{tabular}{|c|c|c|}
\hline & & Mean, std.dev. \\
\hline Intra-firm wage dispersion & $\begin{array}{l}\text { Difference (in \%) between the highest effective hourly } \\
\text { wage rate of a skilled blue-collar worker and the lowest } \\
\text { effective hourly wage rate of an unskilled blue-collar } \\
\text { worker in the establishment. }\end{array}$ & $36.55,25.82$ \\
\hline Blue-collar workers & $\begin{array}{l}\text { Unskilled and skilled blue-collar workers as a proportion } \\
\text { of total employees. }\end{array}$ & $.630, .180$ \\
\hline Skilled blue-collar workers & $\begin{array}{l}\text { Skilled blue-collar workers as a proportion of total } \\
\text { employees. }\end{array}$ & $.378, .226$ \\
\hline Temporary workers & Temporary workers as a proportion of total employees. & $.022, .062$ \\
\hline Women & Women as a proportion of total employees. & $.274, .228$ \\
\hline University graduates & $\begin{array}{l}\text { University and college graduates as a proportion of total } \\
\text { employees. }\end{array}$ & $.036, .054$ \\
\hline Establishment size & Total employees in the establishment. & $133.8,194.3$ \\
\hline Single establishment & $\begin{array}{l}\text { Dummy equals } 1 \text { if the establishment has no subsidiaries } \\
\text { and is not itself a subsidiary. }\end{array}$ & $.621, .486$ \\
\hline Shift work & Dummy equals 1 if the establishment uses shift work. & $.449,498$ \\
\hline Sales concentration & $\begin{array}{l}\text { Sales of the six largest companies in each industrial sector } \\
\text { as a share of total sales in the sector. Official German } \\
\text { statistics are matched to } 32 \text { industrial sectors identified by } \\
\text { the survey. }\end{array}$ & $17.41,14.51$ \\
\hline Establishment age & $\begin{array}{l}\text { Dummy equals } 1 \text { if the establishment was created before } \\
1960 .\end{array}$ & $.653, .476$ \\
\hline Technology & $\begin{array}{l}\text { Dummy equals } 1 \text { if the production technology is of the } \\
\text { most recent vintage. }\end{array}$ & $.313, .464$ \\
\hline Managerial profit sharing & $\begin{array}{l}\text { Dummy equals } 1 \text { if the executive managers have a profit- } \\
\text { sharing plan. }\end{array}$ & $.483, .500$ \\
\hline Profit sharing for employees & $\begin{array}{l}\text { Dummy equals } 1 \text { if the establishment provides profit } \\
\text { sharing to employees other than executives. }\end{array}$ & $.148, .356$ \\
\hline Piece rates & $\begin{array}{l}\text { Dummy equals } 1 \text { if the establishment uses a piece rate in } \\
\text { its production departments. }\end{array}$ & $.194, .396$ \\
\hline Training & $\begin{array}{l}\text { Expenditures (in German marks) on employer provided } \\
\text { further training divided by total employees. }\end{array}$ & $194.4,551.8$ \\
\hline $\begin{array}{l}\text { Collective bargaining } \\
\text { coverage }\end{array}$ & $\begin{array}{l}\text { Dummy equals } 1 \text { if the establishment is covered by a } \\
\text { collective bargaining agreement. }\end{array}$ & $.663, .473$ \\
\hline Works council & $\begin{array}{l}\text { Dummy equals } 1 \text { if a works council is present in the } \\
\text { establishment. }\end{array}$ & $.617, .487$ \\
\hline Team & $\begin{array}{l}\text { Dummy equals } 1 \text { if blue-collar workers are organized is } \\
\text { production teams with expanded involvement in decision- } \\
\text { making and increased responsibility. }\end{array}$ & $.397, .490$ \\
\hline Team $\mathrm{x}$ establishment age & Works council interacted with establishment age. & $.265, .442$ \\
\hline Team $\mathrm{x}$ training & Team interacted with training. & $82.94,209.8$ \\
\hline Team x technology & Team interacted with technology. & $.130, .337$ \\
\hline $\begin{array}{l}\text { Team } \mathrm{x} \text { collective bargaining } \\
\text { coverage }\end{array}$ & Team interacted with collective bargaining coverage. & $.255, .436$ \\
\hline Team x works council & Team interacted with works council. & $.246, .431$ \\
\hline $\begin{array}{l}\text { Works council x managerial } \\
\text { profit sharing }\end{array}$ & Works council interacted with managerial profit sharing. & $.351, .478$ \\
\hline $\begin{array}{l}\text { Works council x collective } \\
\text { bargaining coverage }\end{array}$ & $\begin{array}{l}\text { Works council interacted with collective bargaining } \\
\text { coverage. }\end{array}$ & $.499, .500$ \\
\hline Industry Dummies & 3 broad defined industry dummies. & \\
\hline
\end{tabular}


Table 2: Determinants of Intra-Firm Wage Dispersion Among Blue-Collar Workers

\begin{tabular}{|c|c|c|}
\hline & (1) & (2) \\
\hline Constant & $17.99(4.21)^{* * *}$ & $19.67(6.40)^{* * *}$ \\
\hline Blue-collar workers & $-1.566(.40)$ & $-2.285(.86)$ \\
\hline Skilled blue-collar workers & $7.266 \quad(2.36)^{* *}$ & $6.097(2.91)^{* * *}$ \\
\hline Temporary workers & $55.82(6.03)^{* * *}$ & $54.62(8.73)^{* * *}$ \\
\hline Women & $8.201(2.41)^{* *}$ & $8.265(3.67)^{* * *}$ \\
\hline University graduates & $15.78(1.30)$ & -.7067 (.09) \\
\hline Establishment size & $.0160(4.08)^{* * *}$ & $.0163(6.16)^{* * *}$ \\
\hline Single establishment & $-.9817(.71)$ & $-2.420(2.64) * * *$ \\
\hline Shift work & $5.888(3.84)^{* * *}$ & $4.647(4.52)^{* * *}$ \\
\hline Product market concentration & $.0799(1.70)^{*}$ & $.1270(3.97)^{* * *}$ \\
\hline Establishment age & $-.7646(.57)$ & 1.505 (1.29) \\
\hline Technology & $-1.193(.88)$ & $-3.945(3.35) * * *$ \\
\hline Managerial profit sharing & $3.364(2.45)^{* *}$ & $5.662(3.96)^{* * *}$ \\
\hline Profit sharing for employees & $-1.683(.91)$ & $-1.875(1.50)$ \\
\hline Piece rates & $-.6298(.38)$ & $1.983(1.78)^{*}$ \\
\hline Training & $.0020(2.47)^{* *}$ & $.0027(6.15)^{* * *}$ \\
\hline Collective bargaining coverage & $1.106(.75)$ & $1.185(.74)$ \\
\hline Works council & $-3.471(2.20)^{* *}$ & $-4.493(2.37)^{* *}$ \\
\hline Teams & $2.964(2.28)^{* *}$ & $5.206(2.72)^{* * *}$ \\
\hline Team $\mathrm{x}$ establishment age & ----- & $-6.640(3.62) * * *$ \\
\hline Team $\mathrm{x}$ training & ----- & $.0083(4.26)^{* * *}$ \\
\hline Team $\mathrm{x}$ technology & ----- & $6.471(3.57) * * *$ \\
\hline Team x collective bargaining coverage & $\begin{array}{ll}---- \\
\end{array}$ & $-5.016(2.54) * *$ \\
\hline Team $\mathrm{x}$ works council & $\begin{array}{c}---- \\
\end{array}$ & $2.015(1.04)$ \\
\hline Works council x managerial profit sharing & ----- & $-3.470(1.94)^{*}$ \\
\hline Works council x collective agreement & ----- & $3.513(1.79)^{*}$ \\
\hline Industry Dummies & Included & Included \\
\hline Pseudo $R^{2}$ & .0763 & .0854 \\
\hline$N$ & 499 & 499 \\
\hline
\end{tabular}

Method: LAD. T-statistics are in parentheses. * Statistically significant at the .10 level; ${ }^{* *}$ at the .05 level; *** at the .01 level. 


\title{
Endnotes
}

\begin{abstract}
${ }^{1}$ Note that production workers are typically in blue-collar occupations (Berman et al. 1998).
${ }^{2}$ Note that this finding applies to heterogeneity in skills and abilities. In contrast, there appears to be no consistent link between racial or gender diversity and team performance (Kochan et al. 2003).

${ }^{3}$ Garicano and Rossi-Hansberg (2006) provide a general theoretical analysis showing that improved communication results in an increased specialization of high-ability and low-ability agents. We apply this idea to the division of labor within teams.
\end{abstract}

${ }^{4}$ Winter (2004) presents a stylized model that differential rewards may even be optimal if teams are homogeneous. In the model, the team members' efforts increase the chance that the team succeeds. If workers shirk, the probability of success is low but strictly positive. It is optimal for the firm that an arbitrarily chosen team member receives a larger reward for good team performance than the other members of the team. If the reward is sufficiently large, the dominant strategy of the chosen team member is to exert high effort (regardless if there is a low or a high probability that the team succeeds). Assuming that team members' efforts are complementary, this in turn induces high effort even by those who only receive smaller rewards. It appears to be reasonable to hypothesize that in heterogenous teams high-ability team members will receive these larger rewards as they have a stronger influence on the success of the team.

${ }^{5}$ See Shapiro and Stiglitz (1984) for a classic efficiency wage model.

${ }^{6}$ Baker et al. (1988) provide a discussion on objective and subjective performance measures.

${ }^{7}$ Heywood et al. (2007) stress that performance appraisals are not only important to detect shirking on the job but also to monitor absence from the job.

${ }^{8}$ See also Dolan et al. (2007) for a discussion on procedural justice.

${ }^{9}$ Flexible automation in the automobile industry is a typical example (Pil and MacDuffie 1996). Flexible automation is used to generate more product variety and to facilitate rapid changes from one model to another. This requires flexible workers who perform a variety of complex tasks and are accustomed to modifying work methods. Moreover, if (minor) modifications in the software programs for robots are carried out locally, flexible production lends itself to increased involvement in making incremental process changes. 
$\overline{{ }^{10} \text { Although centralized collective bargaining in Germany is coming under increasing threat, the share }}$ of establishments covered by firm-specific agreements is very small. Addison et al. (2007) report for the year 2004 that 41 percent of all West German establishments were covered by industry-level agreements and only 2 percent were covered by firm-level agreements. Instead of switching from industry-level bargaining to firm-level bargaining, employers tend to escape collective bargaining completely. Since the 1990s there is a substantial decline in collective bargaining coverage.

${ }^{11}$ This may explain why the empirical literature on this topic is inconclusive. Also, studies for Germany report very mixed results. While Stephan and Gerlach (2005) find that collective bargaining is associated with reduced wage dispersion, Hubler and Meyer (2001) obtain the opposite result.

${ }^{12}$ However, due to data limitations, their control group includes both establishments without teams and establishments that already have teams.

${ }^{13}$ Similarly, Helper et al. (2002) use an index of employee involvement practices to examine the wage effect of those practices. They find that employee involvement is associated with higher wages for blue-collar workers in the auto-supply industry. However, Helper et al. (2002) do not consider the effects of employee involvement on wage inequality within establishments.

${ }^{14}$ Note that this information is only available from the fourth wave of the panel. Only wage dispersion among blue-collar workers was addressed.

${ }^{15}$ Descriptive statistics and multivariate analyses are not weighted. The sampling weights available in the data set only correct for stratification by establishment size. Thus, using the weights in multivariate regressions will probably result in biased estimates. A more appropriate method is to control for the two stratification characteristics establishment size and industry in the regressions (Winship and Radbill 1994). To relate descriptive statistics to regression results, they are also not weighted.

${ }^{16}$ Similarly, Jirjahn (2007) finds that establishments with a high share of unskilled blue-collar workers are more likely to use shift work. These establishments also have a higher share of shift workers.

17 This effect is obtained by the following calculation: $5.206+0.0083 \times 200=6.866$. Similar calculations apply for the other moderating variables. 